J. Clin. Chem. Clin. Biochem.

Vol. 17, 1979, pp. 483-488

\title{
Evaluation of Enzyme Immunoassays for Determination of Thyroxine (EMIT, ENZYMUN) and of Thyroxine Binding Index
}

\author{
By M. Oellerich, H. Haindl and R. Haeckel \\ Technical Assistance: I. Isberner, B. Störmer and M. Beilstein \\ Institut für Klinische Chemie und Institut für Nuklearmedizin, Medizinische Hochschule Hannover
}

(Received August 28, 1978/January 23, 1979)

Summary: An evaluation of enzyme immunoassays for determination of thyroxine in serum (EMIT ABA thyroxine assay, Syva Corp., ENZYMUN assay thyroxine, Boehringer Mannheim) and of thyroxine binding index (ENZYMUN assay $\mathrm{TBI}^{1}$ ), Boehringer Mannheim) is presented. The precision of the enzyme immunoassays was adequate (coefficients of variation ranged from day to day with EMIT from 3-11\% and with ENZYMUN from 4-11\%). Both assays are specific and easy to perform. About 20 unknown samples can be analyzed in duplicate by EMIT within 60 minutes and by ENZYMUN within 250 minutes. A comparison of the results obtained by enzyme immunoassays and radioimmunoassay in a series of about 100 patients showed a good correlation between both methods. The precision of the ENZYMUN TBI assay was adequate (coefficient of variation from day to day $4.9 \%$ ) and the thyroxine/TBI-ratio correlated well with the thyroxine/TBG-ratio.

\section{Erprobung von Enzym-Immuno-Tests zur Bestimmung von Thyroxin (EMIT, ENZYMUN) und des Thyroxin-Bin- dungs-Index}

Zusammenfassung: Eș wird über eine Erprobung von Enzym-Immuno-Tests zur Bestimmung von Thyroxin im Serum (EMIT ABA Thyroxin Test, Syva Corp., ENZYMUN-Test Thyroxin, Boehringer Mannheim) und des Thyroxin-Bindungs-Index (ENZYMUN-Test TBI ${ }^{1}$ ), Boehringer Mannheim) berichtet. Die Präzision der Enzym-Immuno-Tests war ausreichend (die Variationskoeffizienten lagen von Tag zu Tag mit EMIT bei 3-11\% und mit ENZYMUN bei 4-11\%). Beide Tests sind spezifisch und rasch durchführbar. Etwa 20 unbekannte Proben können als Doppelbestimmungen mit EMIT in 60 Minuten und mit ENZYMUN in 250 Minuten durchgeführt werden. Ein Vergleich der Ergebnisse, welche mit den Enzym-Immuno-Tests und einem Radioimmunotest bei einer Serie von etwa 100 Patienten erhalten wurden, zeigte eine gute Úbereinstimmung beider Methoden. Die Präzision des ENZYMUN TBI-Tests war ausreichend (Variationskoeffizient von Tag zu Tag 4,9\%) und der Thyroxin/TBI-Quotient korrelierte gut mit dem Thyroxin/TBGQuotienten.

\section{Introduction}

Enzyme immunoassays have gained increasing interest for routine analysis in the last few years. In comparison with radioimmunoassay this technique has the advantage that no radioactive material is used, the standard equipment of routine laboratories can be used, and the reagents have a longer shelf life. A number of enzyme immunoassays have already been mechanized and are successfully applied in routine laboratories $(1-6)$.

Enzyme immunoassays ${ }^{2}$ ) for the determination of thyroxine and thyroxine binding index (TBI), based either on the EMIT technique (7-8) (EMIT thyroxine asssay, Syva Corp., Palo Alto, U.S.A.) or on an ELISA procedure (9-10) (ENZYMUN assay thyroxine, ENZYMUN assay TBI, Boehringer Mannheim, D-6800 Mannheim), have recently become commercially available.

The results of an evaluation of these enzyme immunoassays are presented in this study.

\footnotetext{
1) The trade name has recently been changed to ENZYMUNTest TBK.

2) Abbreviations: EMIT $^{R}$ = Enzyme multiplied immunoassay technique, ELIŚA = Enzyme linked immunosorbent assay, ENZYMUN ${ }^{R}$ = trade name for various enzyme immunoassays based on the ELISA technique, RIA = radioimmunoassay, TBI = thyroxine binding index, TBG = thyroxine-binding globulin, $\mathrm{FTI}=$ free thyroxine index, $\mathrm{T}_{4}=$ thyroxine, $\mathrm{T}_{3}=$ triiodothyronine.
} 


\section{Materials and Methods}

\section{Materials}

The reagents for the EMIT ABA thyroxine assay were provided by E. Merck (D-6100 Darmstadt). Reagents for the ENZYMUN assays, thyroxine and TBI were from Boehringer Mannheim (D-8132 Tutzing). Kits for the determination of thyroxinebinding globulin (RIA-GNOST, TBG) were purchased from Behring-Werke (D-3550 Marburg). Triiodothyronine, Triiodothyroacetic acid and tetraiodothyroacetic acid were a generous gift from Henning (D-1000 Berlin). $L$-thyroxine was purchased from Sigma (D-8021 Taufkirchen).

\section{Enzyme immunoassays}

Thyroxine was assayed by the EMIT ABA thyroxine assay designed for use with the ABA 100 Bichromatic Analyzer (Abbott, D-6070 Langen) equipped with an auxiliary dispenser.

Determinations of thyroxine and TBI by ENZYMUN assays were carried out with an Eppendorf system 5090 (Eppendorf; D-2000 Hamburg 63) at a wavelength of $405 \mathrm{~nm}$.

All of these enzyme immunoassays (EMIT, ENZYMUN) were performed according to the manufacturer's instructions. Unknown samples were analyzed by EMIT in duplicate and by ENZYMUN in triplicate, as recommended by the manufacturers.

\section{Radioimmunoassays}

Thyroxine determinations by radioimmunoassay were carried out with a double antibody technique, which is used as the present routine procedure.

$20 \mu$ l of serum or thyroxine standard (A), $400 \mu 1$ of barbital buffer containing [ $\left.{ }^{125} I\right] L$-thyroxine (B), $200 \mu$ l of antiserum against thyroxine (C) and $100 \mu$ l of precipitating antiserum (D) are incubated for 18 hours at room temperature. The samples are then centrifuged for 15 minutes at $2400 \mathrm{~g}$ and the supernatant is discarded. The pellet is washed once with $1 \mathrm{ml}$ of bidistilled water. The antibody-bound radioactivity is measured using gamma counters (Berthold, D-7547 Wildbad; Packard, D-6000 Frankfurt/M.). All samples were analyzed in duplicate. Standard curves were calculated by "spline function" (11) using a Diehl Alphatronic calculator (Diehl, D-8500 Nürnberg).

\section{Reagents}

(A) Thyroxine-free serum was prepared according to Meinhold \& Wenzel (12). Charcoal (200 g, Norit A, Serva, D-6900 Heidelberg) was added to pool serum (1 l), stirred overnight at $4^{\circ} \mathrm{C}$ and then centrifuged for 8 hours at $20000 \mathrm{~g}$. The supernatant was filtered using quartz wool and then spiked with $L$-thyroxine (Henning, D-1000 Berlin) (19-618 nmol/1).

(B) Barbital buffer (pH 8.4) contains: $80 \mathrm{mmol} / 1$ barbital (5,5' diethyl-barbituric acid-sodium salt) (Merck, D-6100 Darmstadt), $10 \mathrm{mg} / 1$ rabbit $\gamma$-globulin (Serva, D-6900 Heidelberg), $1 \mathrm{~g} / \mathrm{l}$ human serum albumin (Behring, D-3550 Marburg), 1.108 $\mathrm{mmol} / 1$ ANS (ammonium salt of 1-anilino-8-naphthalene-sulfonic acid (Serva, D-6900 Heidelberg); $72.5 \mathrm{pmol} / 1$ [ $\left.^{125} \mathrm{I}\right] L$-thyroxine (specific radioactivity $28749 \mathrm{MBq} / \mu \mathrm{mol}$, Rohstoffeinfuhr, D-4000 Düsseldorf), $0.5 \mathrm{mmol} / 1$ merthiolate (sodium salt of ethylmercurithiosalicylic acid) (Merck, D-6100 Darmstadt).

(C) Thyroxine-bovine-serum-albumin-conjugate was prepared according to Oliver (13) and Hesch (14) by coupling $L$-thyroxine-ethylester-hydrochloride (Henning, D-1000 Berlin) to bovine serum albumin (Behring, D-3550 Marburg) using 1 ethyl-3(3dimethylaminopropyl)-carbodiimidehydrochloride (Serva, D-6900 Heidelberg). Two mg of thyroxine-bovine-serum:albumin-conjugate dissolved in $1 \mathrm{ml}$ complete Freund's adjuvant and $9 \mathrm{~g} / 1$ sodium chloride solution (volumes $0.5 \mathrm{ml}+0.5 \mathrm{ml}$ ) were subcutaneously injected at various places on the back of rabbits every 14 days. The reaction medium of the assay contains thyroxine antiserum in a final dilution of 1:5400 (affinity constant $2.5 \times 10^{10} \mathrm{l} / \mathrm{mol}$ )

(D) As precipitating antiserum anti-rabbit $\boldsymbol{\gamma}$-globulin from donkey (Wellcome, D-3006 Großburgwedel) was used (final dilution in the reaction medium 1:144). Thyroxine-binding globulin (TBG) was determined by use of the RIA-GNOST TBG assay according to the instructions of the manufacturer.

Calculation of FTI and $\mathrm{T}_{4} / \mathrm{TBG}$-ratio

FTI was calculated as thyroxine $(\mu \mathrm{g} / \mathrm{dl}) / \mathrm{TBI}$, and $\mathrm{T}_{4} / \mathrm{TBG}$-ratio as thyroxine $(\mu \mathrm{g} / \mathrm{dl}) \times 10000 / \mathrm{TBG}(\mathrm{mg} / \mathrm{l})$.

Reference ranges

Reference ranges for thyroxine, TBG, FTI and $\mathrm{T}_{4} / \mathrm{TBG}$-ratio were used as indicated by the manufacturers of the various kits. With our radioimmunoassay for determination of thyroxine the reference range used was $51.5-167.3 \mathrm{nmol} / 1$. This reference range was established by the analysis of 150 samples from clinically euthyroid patients (age: $20-65$ years). As the results showed a normal distribution the reference range was calculated from the mean value and two standard deviations.

Furthermore, the various reference ranges were examined for their validity for the patient collective tested in this study. It was found that the median of the results obtained with this collective was in each case in the middle of the corresponding reference range. Therefore the use of the mentioned reference ranges appeared to be justified.

Thyroxine values given in $\mu \mathrm{g} / \mathrm{dl}$ are converted into $\mathrm{nmol} / \mathrm{l}$ by multiplication with 12.87 .

\section{Results}

\section{Precision}

With various commercial control sera the coefficients of variation ranged from day to day with EMIT from 3-5\%, with ENZYMUN from 4-7\% and with the radioimmunoassay from $6-8 \%$ (tab. 1). At low thyroxine concentrations $(25-30 \mathrm{nmol} / \mathrm{l})$ coefficients of variation of about $11 \%$ were found with the enzyme immunoassays. These precision data refer to duplicate determinations.

\section{Accuracy}

Average recoveries of thyroxine added to pooled thyroxine-free human serum are shown in table 2 . At various thyroxine concentrations between 64 and $260 \mathrm{nmol} / 1$ the recovery with EMIT was $94-100 \%$, with the ENZYYMUN assay $96-103 \%$, and with the radioimmunoassay $97-107 \%$.

Furthermore the results measured by ENZYMUN thyroxine assay and radioimmunoassay in 107 specimens from patients were compared. The leastsquares regression analysis (fig. 1) showed the slope of the line to be 0.97 . The value of the intercept was 2.7 $\mathrm{nmol} / \mathrm{l}$. The correlation between the results was good $(r=0.972)$. The mean values obtained by ENZYMUN and radioimmunoassay were $121.2 \pm 56.5 \mathrm{nmol} / 1$ and $122.0 \pm 56.5 \mathrm{nmol} / 1$ respectively. A significant difference between the results of both methods was not present (t-value 0.59). Reproducible deviations of more than $30 \%$ between the results of both assays occurregd in 2 out of 107 cases. Only one of these discrepancies was clinically relevant: a hypothyroid patient was erroneously classified euthyroid by the ENZYMUN assay. 
Tab. 1. The precision from day to day of the ENZYMUN-, EMIT ABA assay and radioimmunoassay for determination of thyroxine in serum. Assays were performed in duplicate on various days as indicated and the mean values were used for calculation of the precision.

\begin{tabular}{|c|c|c|c|c|c|c|c|c|c|}
\hline & \multicolumn{2}{|c|}{ ENZYMUN } & \multirow[b]{2}{*}{$n^{b}$} & \multicolumn{3}{|c|}{ EMIT ABA } & \multicolumn{3}{|c|}{ Radioimmunoassay } \\
\hline & $\begin{array}{l}\overline{\mathbf{x}} \\
(\mathrm{nmol} / \mathrm{l})\end{array}$ & $\begin{array}{l}\mathrm{CV}^{\mathrm{a}} \\
(\%)\end{array}$ & & $\begin{array}{l}\bar{x} \\
(\mathrm{nmol} / \mathrm{l})\end{array}$ & $\begin{array}{l}\text { CV } \\
(\%)\end{array}$ & $\mathbf{n}$ & $\begin{array}{l}\bar{x} \\
(\mathrm{nmol} / \mathrm{l})\end{array}$ & $\begin{array}{l}\mathrm{CV} \\
(\%)\end{array}$ & $\mathrm{n}$ \\
\hline $\begin{array}{l}\text { Calibrators } \\
25.7 \mathrm{nmol} / 1 \\
32.2 \mathrm{nmol} / 1 \\
38.6 \mathrm{nmol} / 1 \\
51.5 \mathrm{nmol} / 1\end{array}$ & $\begin{array}{l}- \\
34.0 \\
38.0 \\
-\end{array}$ & $\begin{array}{l}\overline{(11.2)} \\
(6.9) \\
-\end{array}$ & $\begin{array}{l}- \\
10 \\
17 \\
-\end{array}$ & $\begin{array}{l}28.6 \\
- \\
\overline{54.8}\end{array}$ & $\begin{array}{l}(11.4) \\
- \\
- \\
(5.9)\end{array}$ & $\begin{array}{l}20 \\
- \\
\overline{20}\end{array}$ & $\begin{array}{l}- \\
- \\
-\end{array}$ & $\begin{array}{l}- \\
- \\
-\end{array}$ & $\begin{array}{l}- \\
\overline{-} \\
-\end{array}$ \\
\hline $\begin{array}{l}\text { Boehringer Mannheim } \\
\text { control serum }\end{array}$ & 88.8 & $(4.3)$ & 11 & - & - & - & - & - & - \\
\hline Lederle RIA control serum I & 118.4 & $(6.5)$ & 24 & 113.3 & $(4.5)$ & 51 & 103.4 & ( 6.9) & 29 \\
\hline Lederle RIA control serum II & 260.0 & $(4.0)$ & 16 & 249.7 & ( 3.6) & 38 & 247.0 & $(8.0)$ & 28 \\
\hline
\end{tabular}

a) mean value ( $\mathrm{nmol} / \mathrm{l})$ with coefficient of variation in parenthesés.

b) number of days.

Tab. 2. The recovery of thyroxine by ENZYMUN-, EMIT ABA assay and radioimmunoassay in spiked serum samples. Determinations were performed in duplicates on various days.

\begin{tabular}{|c|c|c|c|c|c|c|c|c|c|}
\hline \multirow{2}{*}{$\begin{array}{l}L \text {-Thyroxine } \\
\text { (nmol/l) }\end{array}$} & \multicolumn{9}{|c|}{ Recovery } \\
\hline & \multicolumn{2}{|c|}{$\begin{array}{l}\text { ENZYMUN assay } \\
(\mathrm{nmol} / \mathrm{l}) \quad(\%)\end{array}$} & $\mathrm{n}^{1}$ & \multicolumn{2}{|c|}{$\begin{array}{l}\text { EMIT ABA assay } \\
(\mathrm{nmol} / \mathrm{l}) \quad(\%)\end{array}$} & $\mathrm{n}$ & \multicolumn{2}{|c|}{$\begin{array}{l}\text { Radioimmunoassay } \\
(\mathrm{nmol} / \mathrm{l}) \quad(\%)\end{array}$} & $\mathrm{n}$ \\
\hline $\begin{array}{r}64.4 \\
128.7 \\
193.1 \\
257.4\end{array}$ & $\begin{array}{r}64.4 \\
132.6 \\
186.6 \\
245.8\end{array}$ & $\begin{array}{r}100 \\
103 \\
97 \\
96\end{array}$ & $\begin{array}{l}3 \\
3 \\
3 \\
3\end{array}$ & $\begin{array}{r}64.4 \\
121.0 \\
182.8 \\
244.5\end{array}$ & $\begin{array}{r}100 \\
94 \\
95 \\
95\end{array}$ & $\begin{array}{l}6 \\
3 \\
6 \\
5\end{array}$ & $\begin{array}{r}66.9 \\
137.7 \\
186.6 \\
253.5\end{array}$ & $\begin{array}{r}105 \\
107 \\
97 \\
99\end{array}$ & $\begin{array}{l}3 \\
3 \\
3 \\
3\end{array}$ \\
\hline
\end{tabular}

${ }^{1}$ ) number of days.

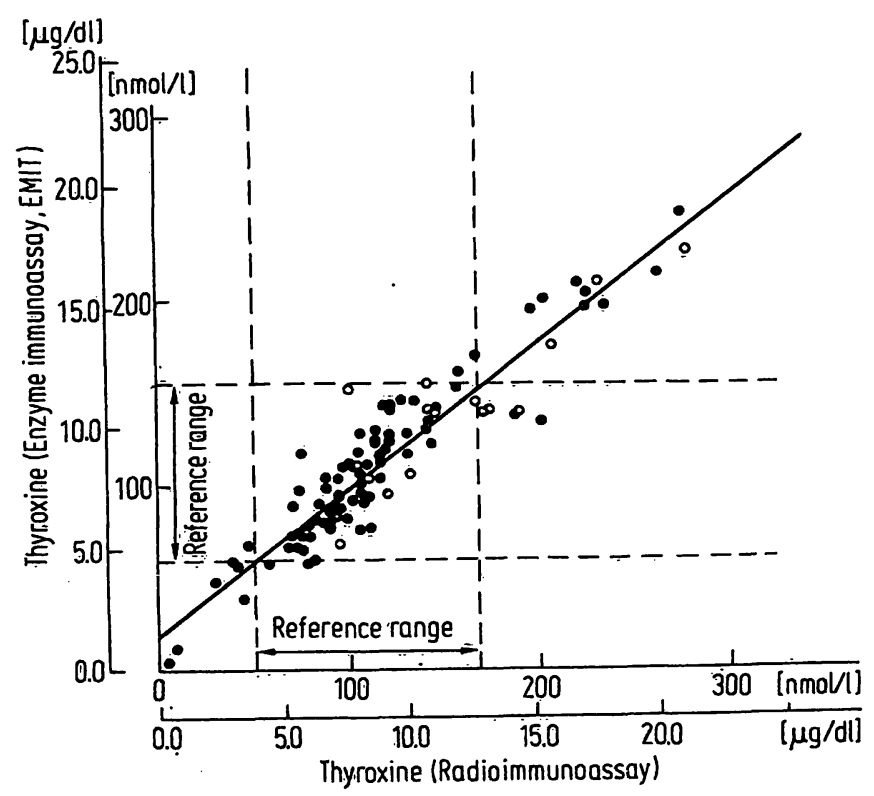

Fig. 1. Serum thyroxine concentrations as measured by enzyme immunoassay (ENZYMUN) and radioimmunoassay $(\mathrm{n}=107)$. Slope: 0.97 , in tercept: $2.7 \mathrm{nmol} / \mathrm{l}$, correlation coefficient: 0.972 . Open circles represent serum samples with elevated concentrations of TBG (>30 mg/l).

The comparison of the results $(n=102)$ obtained by the EMIT ABA thyroxine assay and radioimmunoassay also showed a sufficient correlation of both methods (fig. 2). The values of slope and intercept were 0.80 and $18.9 \mathrm{nmol} / \mathrm{l}$. The coefficient of correlation was

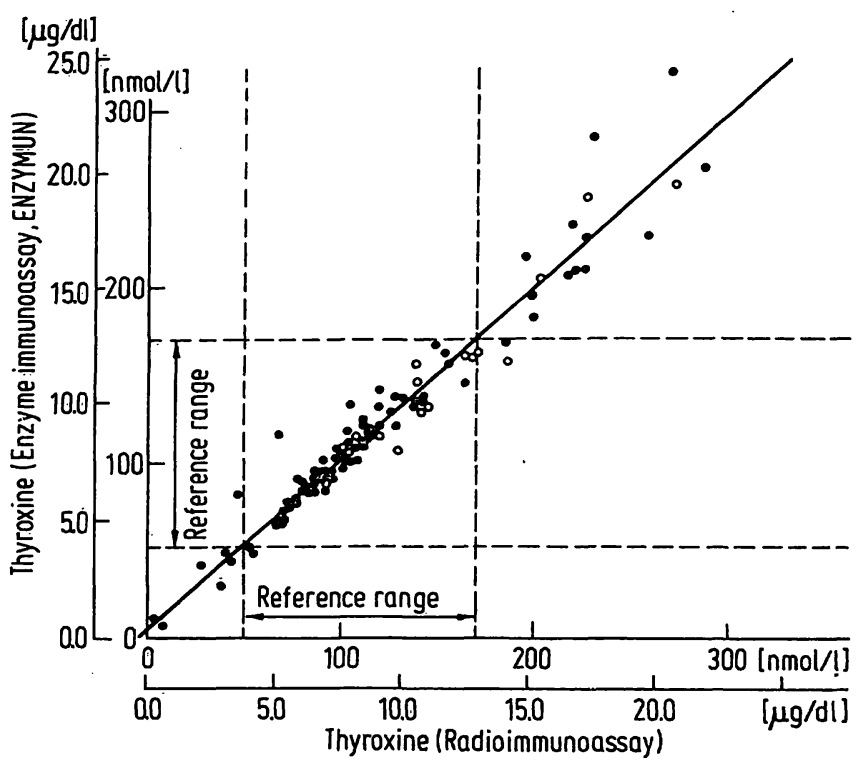

Fig. 2. Serum thyroxine concentrations as measured by enzyme immunoassay (EMIT) and radioimmunoassay $(n=102)$. Slope: 0.80 , intercept: $18.9 \mathrm{nmol} / \mathrm{l}$, correlation coefficient: 0.935 . Open ciroles represent serum samples with elevated concentrations of TBG (>30 mg/l). 
$\mathrm{r}=0.935$. The mean value of the results determined by $\operatorname{EMIT}(\bar{y}=114.1 \pm 45.2 \mathrm{nmol} / \mathrm{l})$ was $3.7 \%$ lower than that found with radioimmunoassay $(\overline{\mathrm{x}}=118.5 \pm$ $52.7 \mathrm{nmol} / \mathrm{l})$. The $\mathrm{t}$-value was 2.34 ( $\mathrm{p}<0.0125)$.

Reproducible differences of more than $30 \%$ between the results of both methods occurred in 4 out of 102 cases. Only two of these discrepances were clinically relevant: one hypo- and one hyperthyroid patient were falsely classified euthyroid by the EMIT assay.

The correlation between these enzyme immunoassays and the radioimmunoassay was satisfactory, also when the samples contained elevated concentrations of thyroxine-binding globulin (fig. 1,2).

\section{Specificity}

The specificity of the enzyme- and radioimmunoassays for the determination of thyroxine was tested by the determination of the cross-reactivity with structurally related compounds. The results obtained with spiked thyroxine-free human serum samples are shown in table 3. For each drug the concentration was determined at which it exerts an absorbance or counts per minute equivalent to $25.7 \mathrm{nmol} / 1$ thyroxine in the corresponding enzyme- or radioimmunoassay. Triiodothyronine and the two thyroxine metabolites triiodothyroacetic acid and tetraiodothyroacetic acid (15) showed a distinctly stronger cross-reaction in the EMIT assay than in the ENZYMUN- and radioimmunoassay. As the reference range of these compounds, however, is very low, a relevant interference is usually not to be expected in any of these tests.

\section{Interferences}

Hemoglobin concentrations up to $1.0 \mathrm{~g} / 1$ showed no interference in both enzyme immunoassays.

The influence of lipemia on these tests was studied with lipemic sera $(n=15$; triglyceride concentration: $\bar{x}$ : $11.0 \mathrm{mmol} / 1$, range $3.4-19.8 \mathrm{mmol} / \mathrm{l})$, which were assayed undiluted and after dilution (1:2) with $9 \mathrm{~g} / 1$ sodium chloride solution. Results of diluted samples were multiplied with the dilution factor.

Tab. 3. Cross-reactivity of triiodothyronine and thyroxine metabolites ${ }^{1}$ ) in enzyme immunoassays (EMIT, ENZYMUN) and. a radioimmunoassay (RIA) for determination of thyroxine.

\begin{tabular}{lllll}
\hline & Reference range & EMIT & ENZYMUN & RIA \\
\hline Compound & nmol/1 & nmol/1/2) & nmol $/ 1^{2}$ ) & nmol $/ 1^{2}$ ) \\
Thyroxine & $51.5-167.3$ & 25.7 & 25.7 & 25.7 \\
Triiodothyronine & $1.23-3.69$ & 29.2 & 35.4 & 33.8 \\
Triiodothyroacetic acid & $\left.<0.16^{3}\right)$ & 59.6 & $>1600$ & $>1600$ \\
Tetraiodothyroacetic acid & $1.0-3.9$ & 22.7 & 57.5 & 60.2 \\
\hline
\end{tabular}

1) Substances were added to thyroxine-free human serum.

2) Concentration resulting in an absorbance or in counts per minute equivalent to $25.7 \mathrm{nmol} / 1$ thyroxine.

$\left.{ }^{3}\right)$ Estimated serum concentration (15).

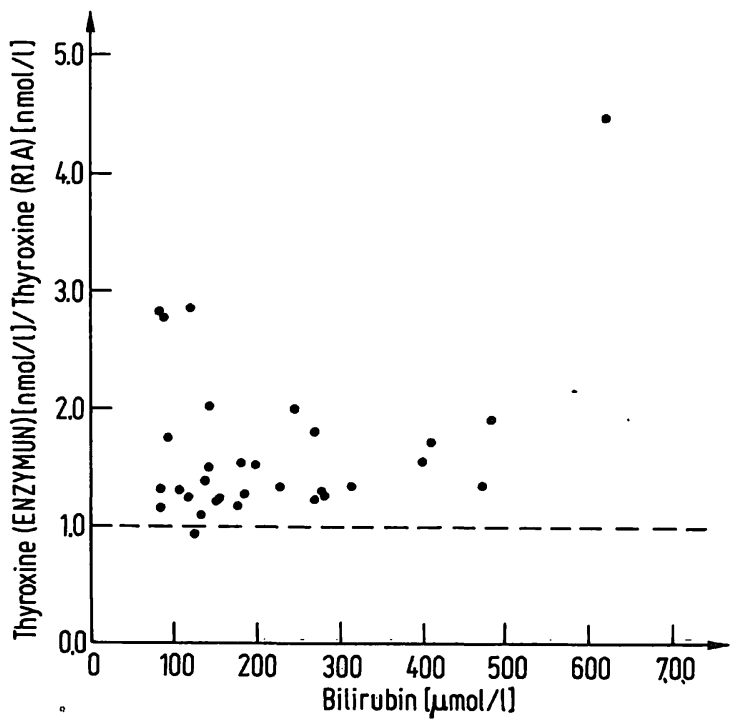

Fig. 3. Deviations between thyroxine determinations by EMIT and radioimmunoassay (calculated as thyroxine (nmol/l) EMIT/thyroxine (nmol/l) radioimmunoassay) in relation to the bilirubin concentrations of the corresponding serum samples $(n=30)$. The dotted line indicates identical results obtained with both radio- and enzyme immunoassay.

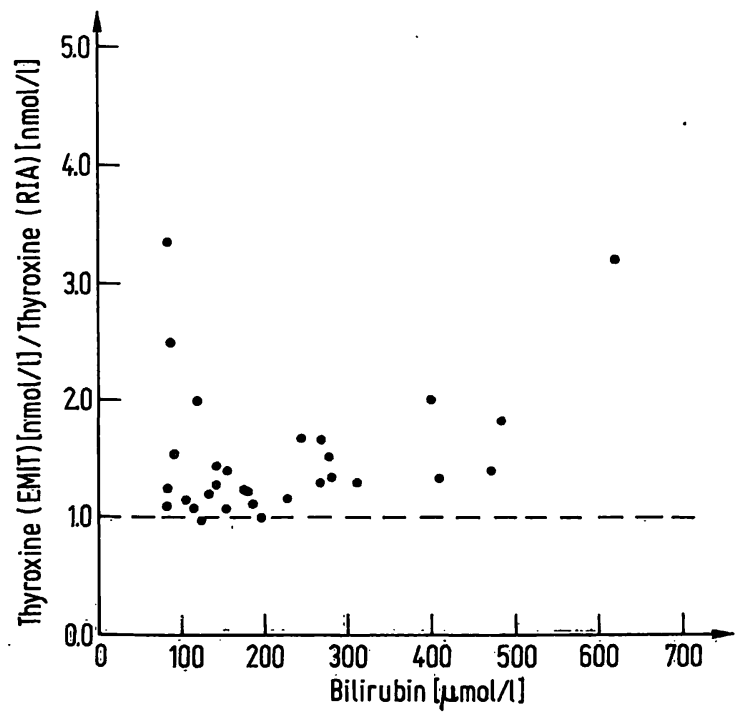

Fig. 4. Deviations between thyroxine determinations by ENZYMUN and radioimmunoassay in relation to the bilirubin concentrations of the corresponding serum samples $(n=30)$. For fur̃ther explanation see legend of fig. 3. 
No interference was found with the ENZYMUN assay (thyroxine (nmol/l): $x: 86.2$; diluted samples, $x: 87.5$ ). With the EMIT assay lower thyroxine concentrations were measured in undiluted samples $(\overline{\mathrm{x}}: 68.2 \mathrm{nmol} / 1$; diluted samples: $\overline{\mathrm{x}}: 81.1 \mathrm{nmol} / \mathrm{l})$.

In icteric sera higher thyroxine concentrations were found by the enzyme immunoassays than by radioimmunoassay. In about $50 \%$ of the determinations the results of the enzyme immunoassays showed a reproducible deviation of more than $30 \%$ from those of the radioimmunoassay. However a clear-cut relationship between these discrepancies and the bilirubin concentration could not be detected (fig. 3, 4). If serum samples were spiked with bilirubin, no interference was found with the radio- and enzyme immunoassays at bilirubin concentrations up to $600 \mu \mathrm{mol} / 1$. So far it cannot be concluded whether bilirubin or another yet unidentified agent which might be present in icteric sera, was responsible for the discrepancies observed. Moreover, it is not clear whether the interference present was in the radio- or in the enzyme immunoassays. Further investigations of this phenomenon are in progress.

\section{Determination of free thyroxine index by ENZYMUN TBI assay}

An enzyme immunoassay for the determination of the thyroxine binding index (TBI), based on the ENZYMUN thyroxine assay, has been developed (10), and it is commercially available. This test can be used like triiodothyronine $\left(\mathrm{T}_{3}\right)$ uptake tests for an indirect estimate of the protein binding of thyroid hormones. $T_{3}$ uptake tests have proved clinically useful and have been combined with measurement of total thyroxine (16) to yield a free thyroxine index (FTI; calculated as $\mathrm{T}_{4} / \mathrm{T}_{3}$ uptake or TBI), which has been found to correlate with both the clinical state of patients and the free $T_{4}$ concentration as measured directly (17). Recently however it was demonstrated that the $\mathrm{T}_{\mathbf{4}}$ /thyroxine-binding globulin (TBG) ratio provides a better index of thyroid function than does FTI $(18,19)$. Therefore we compared the FTI determined by the ENZYMUN assay with the $T_{4} / T B G$ ratio. The correlation between both ratios was good. The serum samples tested contained concentrations of thyroxine-binding globulin between 16 and $48 \mathrm{mg} / 1$ (fig. 5). In the presence of elevated TBG concentrations $(>30 \mathrm{mg} / \mathrm{l})$ the regression line appears to have a higher slope than in the presence of TBG concentrations in the normal range. Discrepancies concerning the classification of patients into eu-, hypo- or hyperthyroid occurred in 6 out of 77 cases. In 5 of these cases the $T_{4} / T B G$ ratio was slightly below the normal range, whereas the $T_{4} / T B I$ ratio was normal. Three of these patients were clinically euthyroid. A relevant discrepancy was present in only one case, which was classified euthyroid by $T_{4} / T B G$ ràtio and hyper-

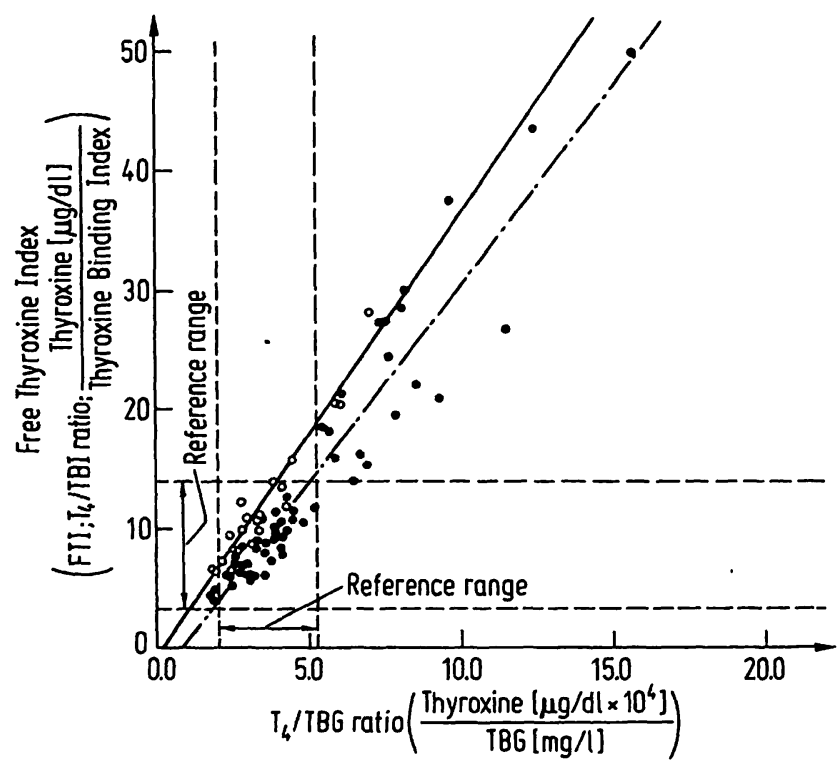

Fig. 5. Correlation between thyroxine/TBG- and thyroxine/TBIratio $(n=77)$. Open circles represent serum samples with elevated concentrations of TBG $(>30 \mathrm{mg} / \mathrm{l})$. $\because-$ regression line in the presence of normal TBG concentrations $(y=3.35 x-2.92) ;-$ regression line in the presence of elevated TBG concentrations $(>30 \mathrm{mg} / \mathrm{l})(\mathrm{y}=3.81$ $x$ - 1.01).

thyroid by FTI. The clinical state of this patient was hyperthyroid. It has to be considered however, that the reference ranges used are preliminary and still the subject of investigation. The precision of the ENZYMUN TBI assay was acceptable. From day to day a coefficient of variation of $4.9 \%$ was obtained $(\bar{x}=1.0 ; n=20$; mean values of duplicate determinations).

\section{Discussion}

Both enzyme immunoassays (EMIT, ENZYMUN) for determination of thyroxine were precise and accurate. As the precision of the ENZYMUN and EMIT assay was satisfactory the performance of the duplicate determinations of unknown samples appears to be adequate.

The results of the enzyme immunoassays correlated well with those obtained by a radioimmunoassay. With few exceptions, the subsequent clinical interpretation was identical for all three methods used.

The linear regression analysis of the results obtained by EMIT and radioimmunoassay points to a proportional error of about $20 \%$ and to a constant error of 18.9 nmol/1 (20). The results of the EMIT assay tended to be higher at thyroxine concentrations below $90 \mathrm{nmol} / \mathrm{l}$ and lower at concentrations above this value than the results determined by radioimmunoassay.

Similar regression constants were found when the EMIT assay was performed with an "Autochemist" analyzer (21), a Kem-O-Mat analyzer (22) or, as in our study, with an ABA 100 analyzer (23). 
Accordingly, the recovery at thyroxine concentrations above $129 \mathrm{nmol} / \mathrm{l}$ was only about $95 \%$ (tab. 2) and at lower concentrations (38.6 nmol/1) 107\%(23). As the Syva Corp. recommends an upper limit of the euthyroid range which is about $10 \%$ lower and a lower limit which is about $10 \%$ higher than that used with the radioimmunoassay, these deviations had no relevant influence on the clinical interpretation of the results.

Both enzyme immunoassays are easy to perform. 20 unknown duplicate samples can be analyzed by the EMIT ABA assay within 60 minutes and by the ENZYMUN assay within 250 minutes.

The ENZYMUN TBI assay seems to be suitable for an indirect estimate of the protein binding of thyroid hormones. $\mathrm{A}_{3}$-uptake test based on the EMIT technique has also been described (24). The direct measurement of
TBG has the advantage that it is better standardized than indirect methods, and it is independent of the endogenous thyroid hormone concentration. Therefore the direct determination of TBG is preferred by various authors $(25,26)$.

In summary it is concluded from our results that the enzyme immunoassays tested (EMIT, ENZYMUN) can be used as well as radioimmunoassay for the determination of thyroxine and TBI in serum. If only in-vitro procedures are considered, the determination of an index of free thyroxine is reportedly sufficient for primary thyroid diagnostic and therapy control in about $60-70 \%$ of all cases of an unselected patient collective (27). Thus a relatively large proportion of in vitro thyroid diagnostic may be reliably conducted by the enzyme immunoassays tested in this study.

\section{References}

1. Schuurs, A. H. W. M. and van Weemen, B. K. (1977), Clin. Chim. Acta 81, 1-40.

2. Oellerich, M. \& Haeckel, R. (1978) in: Rationalisierung des medizinischen Laboratoriums (Haeckel, R., ed.), GIT-Verlag, Darmstadt, in press.

3. Haeckel, R. \& Oellerich, M. (1977), Lab. Med. 7, 1-12.

4. Oellerich, M., Külpmann, W. R. \& Haeckel, R. (1977),

J. Clin. Chem. Clin. Biochem. 15, 275-283.

5. Oellerich, M., Külpmann, W. R., Haeckel, R. \& Heyer, R. (1977), J. Clin. Chem. Clin. Biochem. 15, 353-358.

6. Oellerich, M., Haindl, H. \& Haeckel, R. (1978), Internist 19, 188-190.

7. Ullmann, E. F., Blakemore, J., Leute, R. K., Eimstad, W. \& Jaklitsch, A. (1975), Clin. Chem. 21, 1011.

8. Jaklitsch, A. P., Schneider, R. S., Johannes, R. J., Lavine, J. E. \& Rosenberg, G. L. (1976), Clin. Chem. 22, 1185.

9. Kleinhammer, G., Lenz, H., Linke, R. \& Staehler, F. (1978), in: Enzymimmunoassay, Grundlagen und praktische Anwendung (Vogt, W. ed). G. Thieme Verlag, Stuttgart, 42-51.

10. Kleinhammer, G., Deutsch, G., Linke, R. \& Staehler, F. (1978), Clin. Chem. 24, 1033.

11. Marschner, I., Erhardt, F. \& Scriba, P. C. (1974), Internat. Atomic Energy Agency, Vienna, 1, 111-122.

12. Meinhold, H. \& Wenzel, K. W. (1974), Z. Klin. Chem. Klin. Biochem. 12, 477-486.

13. Oliver, G. G., Parker, B. M., Brasfield, D. L. \& Parker, C. W. (1968), J. Clin. Invest. 47, 1035-1042.
14. Hesch, R. D. \& Hüfner, M. (1972), Acta Biol. Med. Germ. $28,861-864$

15. Burger, A. \& Vallotton, M. B. (1975), In: Thyroid hormone metabolism (Harland, W. A. \& Orr, J. S. eds.), Academic Press, San Francisco, 223-239.

16. Howorth, P. J. N. \& MacLagen, N. F. (1969), Lancet $I$, 224-228.

17. Wellby, M. L., O'Halloran, M. W. \& Marshall, J. (1974), Clin. Endocrinol. 3, 63-68.

18. Burr, W. A., Ramsden, D. B., Evans, S. E., Hogan, T. \& Hoffenberg, R. (1977), Brit. Med. J. 1, 485-488.

19. Pickardt, C. R., Bauer, M., Horn, K., Kubiczek, Th. \& Scriba, P. C. (1977), Internist $18,538-543$.

20. Westgard, J. O. \& Hunt, M. R. (1973), Clin. Chem. 19, $49-57$.

21. Galen, R. S. \& Forman, D. (1977), Clin. Chem. 23, 119-121.

22. Riesen, W. F., Muacevic, B. \& Jaggi, M. (1978), J. Clin. Chem. Clin. Biochem. 16, 387-389.

23. Finley, P. R. \& Williams, R. J. (1978), Clin. Chem. 24, $165-167$.

24. Greenwood, H. M., Jaklitsch, A. P., Brown, A. G. \& Winfrey, L. J. (1978), IXth international congress of clinical chemistry, Mexico, Abstracts, p. 110.

25. Horn, K., Kubiczek, Th., Pickardt, C. R. \& Scriba, P. C. (1977), Klin. Wochenschr. 55, 881-894.

26. Hesch, R. D. (1977), Dtsch. Med. Wochenschr. 102, 13861.388 .

27. Emrich, D. (1978), Therapiewoche 28, 5053-5060.

Priv.-Doz. Dr. M. Oellerich Institut für Klinische Chemie Karl-Wiechert-Allee 9 D-3000 Hannover 61 


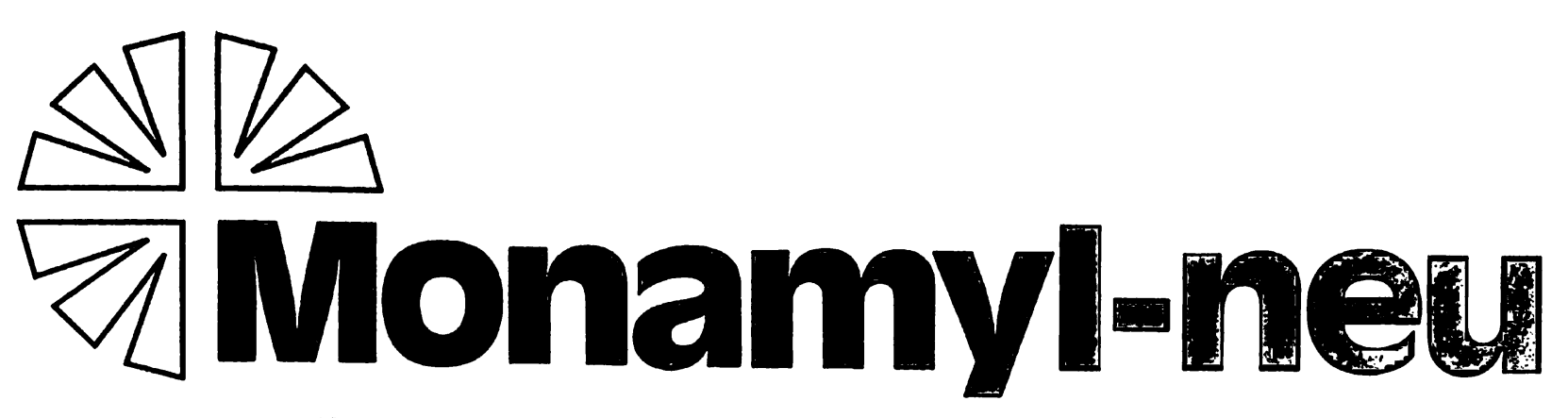

\section{Vollenzymatischer alpha-Amylase-Test Substrat: Maltotetmaose}

\section{Es gibt vier gute Grübrade, die für dieses menne verffaloren sprechen - denin es ist}

\section{Spezifisch}

... denn die kinetische UV-Methode, sowie das definierte Substrat, erlaubt Innen eine absolute Spezifizierung.

\section{Automatisierbalr}

... denn Automatisierung ist rationell und bedeutet höchste Wirtschaftlichkeit für Sie.

\section{Sicher}
... denn durch die NADH-Messung erhalten Sie absolute und sichere Werte;
... und endogene Glucose stört nicht.

\section{Einfach}

... denn mit nur einem gefriergetrockneten Fertigreagenz

benötigen Sie nur einen Pipettierschritt und sparen Arbeitsschritte und Arbeitszeit;

... zentrifugieren, Leerwerte usw. können Sie sich sparen.

\section{Der problemlose Test mit dem optimalen Substrat.}

Abpackungen: $10 \times 31$ Mikro/10 $\times 15$ Halbmikro jetzt neu: $6 \times 7$ Mikro/ $6 \times 3$ Halbmikro

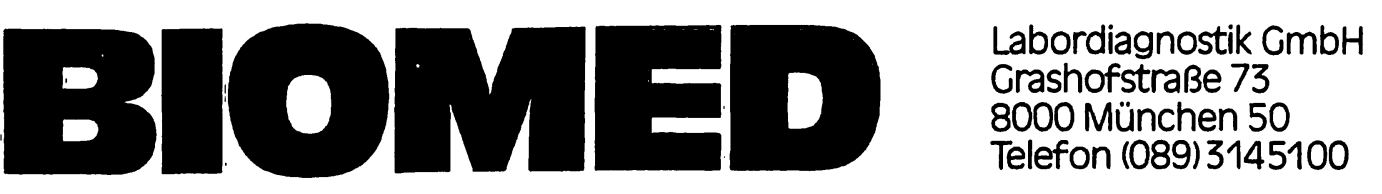




\section{Domschke/Koch}
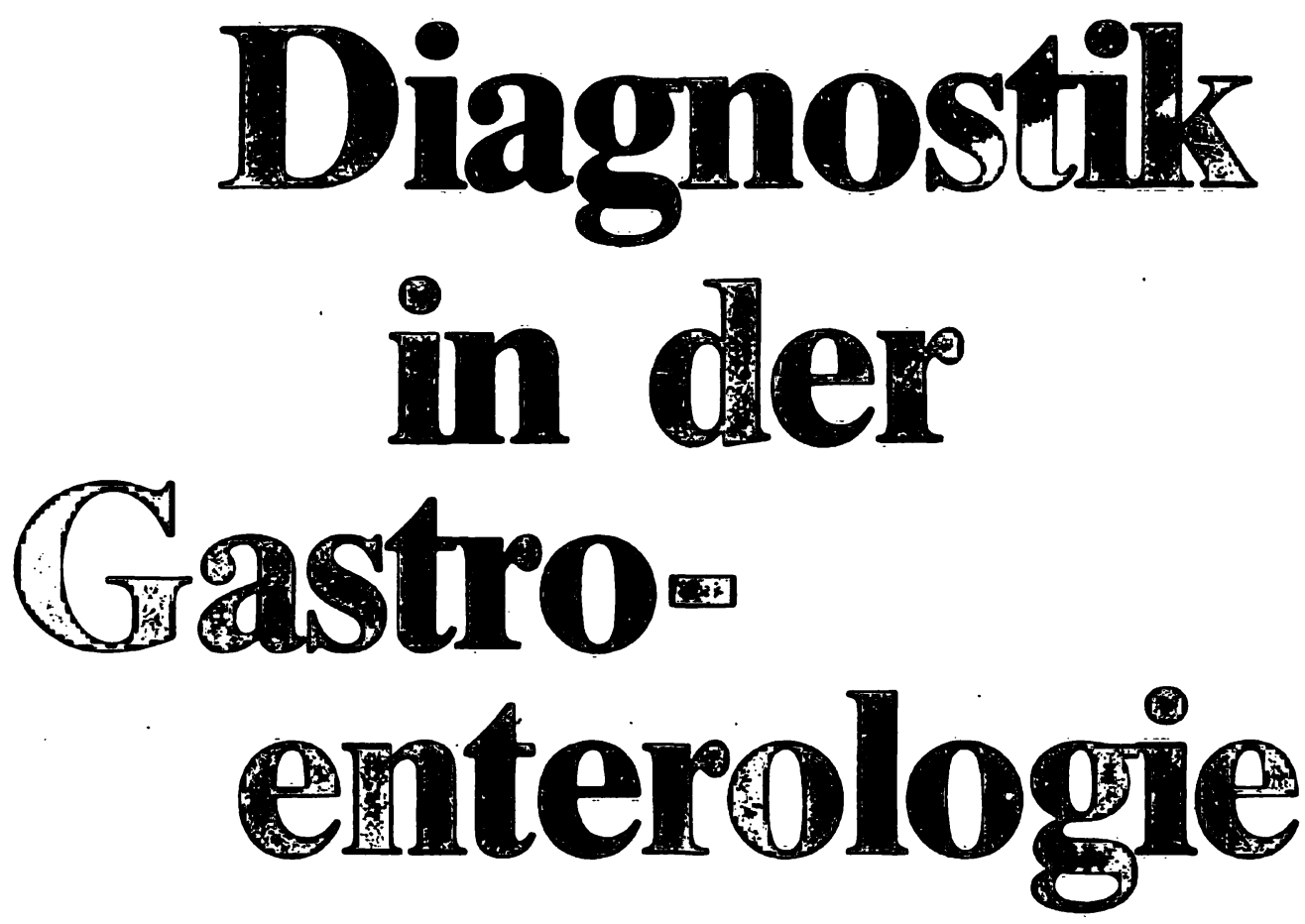

Methodik und Bewertung

Coupon

Ich bestelle aus dem

Georg Thieme Verlag, Stuttgart über die Buchhandlung:

Expl. Domschke/Koch (Hrsg.) Diagnostik in der Gastroenterologie 1979. 448 S., 317 Abb. 105 Tab., geb. DM 128,ISBN 3135728013 